African Crop Science Journal by African Crop Science Society is licensed under a Creative Commons Attribution 3.0 Uganda License. Based on a work at www.ajol.info/ and www.bioline.org.br/cs DOI: http://dx.doi.org/10.4314/acsj.v26i2.8

\title{
TRAIT ASSOCIATION AND STABILITY OF VIRUS RESISTANCE AMONG COWPEA GENOTYPES IN UGANDA
}

\author{
E.K. MBEYAGALA ${ }^{1,2}$, J. BISIKWA ${ }^{1}$, P. TUKAMUHABWA ${ }^{1}$ and S.B. MUKASA ${ }^{1}$ \\ ${ }^{1}$ School of Agricultural Sciences, Makerere University, P. O. Box 7062, Kampala, Uganda \\ ${ }^{2}$ National Semi-Arid Resources Research Institute (NaSARRI)/NARO, P. O. Box 56, Soroti, Uganda \\ Corresponding author: kmbeyagala@gmail.com
}

(Received 23 October, 2017; accepted 24 May, 2018)

\begin{abstract}
Cowpea (Vigna unguiculata L. Walp) grain constitutes an important source of protein for several households in Sub-Saharan Africa. However, widespread occurrence of viral diseases is a serious constraint to productivity of the crop and its nutritional value in terms of grain protein content. This study was carried out to identify cowpea genotypes with the best combination of virus resistance, maturity traits and yield stability. A screening trial for 105 genotypes was established in three locations (Budaka, Tororo and Serere) in Uganda for two consecutive seasons to assess for virus resistance, maturity traits and yield. Season and genotypic effects had a greater contribution to the variation in virus infection among genotypes. Eight genotypes (WC48, NE43, NE15, WC35A, WC39, WC33, WC35C, and WC18) showed low virus infection levels. The three locations formed a single megaenvironment with WC51, NE48, and MU17 having the highest mean yield (1,384, 1,191.4 and 1,119.6 kg ha-1), respectively, as well as exhibiting yield stability across locations. Days to first flower, mid-bloom (days to 50\% flowering) and days to maturity were positively associated. Virus severity, incidence and AUDPC also had a positive association indicating that indirect selection based on any of these traits is possible. Potential sources of resistance to virus infection exist among the evaluated genotypes. Further screening under high viral pressure is recommended. The high yielding genotypes are recommended for release for cultivation.
\end{abstract}

Key Words: AUDPC, incidence, severity, Vigna unguiculata

\section{RÉSUMÉ}

Lesgrains du niébé (Vigna unguiculata L. Walp) constituent une source importante de protéine pour un nombre important de ménages en Afrique Sub-Saharienne. Toutefois, la prolifération des maladies virales est une contrainte sérieuse à la productivité de la culture et sa valeur nutritionnelle en termes de la teneur en protéine. Cette étude a été conduite pour identifier les génotypes du niébé avec une meilleure combinaison de résistance au virus, traits de maturité et la stabilité du rendement en grain. Un essai de criblage de 105 génotypes a été établi dans trois localités (Budaka, Tororo et Serere) en Uganda pendant deux saisons consécutives pour évaluer la résistance au virus, traits de maturité et le rendement. Les effets de la saison et du génotypeont contribué beaucoup plus à la variation dans l'infection du virus parmi les génotypes. Huit génotypes (WC48, NE43, NE15, WC35A, WC39, WC33, WC35C, et WC18) ont montré de faibles niveaux d'infection du virus.Les trois localités ont formé un méga-environnement avec WC51, NE48 et MU17 ayant les plus grands rendements moyens (1 $384 ; 1$ 191,4 et1119,6 kg ha- ${ }^{1}$ ), respectivement, de même la stabilité du rendement à travers les localités. Le nombre de jours de la première floraison, mid-floraison (nombre de jours de 50\% floraison) et le nombre de jours de maturité étaient associés positivement. La sévérité de virus, l'incidence et l'AUDPC ontaussi une association positive indiquant 
que la sélection indirecte basée sur n'importe quel de ces traits est possible. Des sources potentielles de résistance à l'infection des virus existent parmi les génotypes évalués. Un criblage sous une forte pression des virus est recommandé. Les génotypes à haut rendement sont recommandés pour délivrance pour production.

Mots Clés: AUDPC, incidence, severité, Vigna unguiculata

\section{INTRODUCTION}

Cowpea (Vigna unguiculata L. Walp) is a key grain legume especially in Sub-Saharan Africa, as an inexpensive source of protein (Timko et $a l ., 2007)$. The grain is highly preferred for its flavour and short cooking time. The crop also is a soil ameliorant through biological nitrogen fixation (Blade et al., 1997; Carsky et al., 2002). Furthermore, cowpea haulms provide fodder for livestock feeding, especially during the dry season (Blade et al., 1997). In addition to the grain, the young leaves/shoots and immature pods are important sources of food and income in Africa (Timko et al., 2007).

Given its roles in contributing to food security, income generation and maintenance of the ecosystem, the crop is truly "a multifunctional legume" (Timko and Singh, 2008). In Uganda, 90\% of cowpea production takes place in the eastern and northern regions of the country, largely by small holder farmers (Adipala et al., 1999). Productivity of the crop is, however low, estimated at less than $500 \mathrm{~kg}$ $\mathrm{ha}^{-1}$. This is attributed to a number of biotic and abiotic factors, as well as poor agronomic practices (Edema et al., 1997; Adipala et al., 1999). Among the biotic constraints, viral diseases which are widespread in the country (Edema et al., 1997; Adipala et al., 1999; Orawu et al., 2005; 2015) contribute greatly to yield reduction. Virus infection of cowpea does not only lead to yield reduction, but also reduces the protein content of the grain (Taiwo and Akinjogunla, 2006).

Breeding for resistance to virus infections is the most cost effective and environmentally friendly approach (Ndiaye et al., 1993; Bashir et al., 2002). This can be achieved through identification and use of best resistant donors. Selection of genotypes that are good in other aspects on the basis of multiple traits, in addition to disease resistance, is therefore important in crop improvement (Yan and Rajcan, 2002). This study was carried out to identify cowpea genotypes with the best combination of virus resistance, maturity traits and yield stability.

\section{MATERIALS AND METHODS}

Study sites and genotypes. This study was carried out during the first and second seasons of 2012 (2012A and 2012B, respectively) at three locations; Serere, Tororo and Budaka districts in eastern Uganda. A total of 105 cowpea genotypes, including local and introduced accessions were evaluated (Table 1). The local genotypes were collected from the northern and eastern regions (N-E), western and central regions (W-C) of the country; while the introductions were obtained from International Institute of Tropical Agriculture (IITA).

An alpha-lattice design was used, with three replicates. Plot size was two rows each of four meters long, with spacing of $60 \mathrm{~cm}$ between and $30 \mathrm{~cm}$ within rows. Post-flowering pests such as flower thrips (Megalurothrips sjostedti Trybom), pod borer (Maruca vitrata Fabricius) and pod sucking bugs were controlled by 3-4 sprays using Roket 44 EC (Profenofos $40 \%$ and Cypermethrin 4\%) starting at the budding stage.

Data collection. Data collection on virus infection commenced three weeks after planting (WAP), and subsequently at 14-days interval until the appearance of the first ripe pods on any of the genotypes. Data were collected on severity of viral symptoms on 10 randomly selected plants in each plot. Disease 
TABLE 1. List of cowpea genotypes evaluated in 2012A and 2012B in a varietal study in Uganda

G53 NE5 NE

\begin{tabular}{lll}
\hline Code & Genotype & Source \\
\hline G1
\end{tabular}

G55 NE50

G56 NE53

G57 NE55

G58

NE6

$\begin{array}{lll}\text { G1 } & \text { EBELAT } & \text { NE } \\ \text { G2 } & \text { ITO0K-835-45 } & \text { IITA }\end{array}$

G59 NE67

G60 NE70

G61 NE71

G62 SECOW2W

G63 WC1

G64 WC10

G65 WC11

G66 WC12

G67 WC13

G68 WC15

G69 WC16

G70 WC17

G71 WC18

G72 WC2

G73 WC21

G74 WC26

G75 WC27

G76 WC29

G77 WC30

G78 WC32

G79 WC33

G80 WC35A

G81 WC35B

G82 WC35C

G83 WC36

G84 WC39

G85 WC4

G86 WC41

G87 WC42

G88 WC44

G89 WC48

G90 WC5

G91 WC51

G92 WC52

G93 WC53

G94 WC55

G95 WC6

G96 WC62

G97 WC63

G98 WC64

G99 WC65

G100 WC66

G101 WC67

G102 WC67A

G103 WC68

G104 WC69

$\mathrm{NE}$

$\mathrm{NE}$

NE

NE

$\mathrm{NE}$

NE

$\mathrm{NE}$

$\mathrm{NE}$

$\mathrm{NE}$

E

WC

WC

WC

WC

WC

WC

WC

WC

WC

WC

WC

WC

WC

WC

WC

WC

WC

WC

WC

WC

WC

WC

WC

WC

WC

WC

WC

WC

WC

WC

WC

WC

WC

WC

WC

WC

WC

WC

WC

WC

WC

G105 WC7 WC

Key: N-E = North-eastern Uganda; E = Eastern Uganda; $\mathrm{W}-\mathrm{C}=$ Western and Central Uganda; $\mathrm{MAK}=$ Makerere collection; IITA = International Institute of Tropical Agriculture 
severity was based on visual estimation of the diseased plants, as manifested by the different symptoms, on a scale of 1-5 [1 = no symptoms on all leaves, $2=$ slight symptoms ( 1 to $25 \%$ of the leaves infected), $3=$ moderate symptoms (26 to $50 \%$ leaves infected), $4=$ prominent symptoms with stunting (51 to $75 \%$ of leaves infected), $5=$ highly severe symptoms with stunting ( $>75 \%$ of leaves infected)] (Gumedzoe et al., 1997). Virus incidence data was recorded as percentage of symptomatic/ diseased plants in each plot as:

Number of diseased plants

Total number of plants

Data on agronomic traits such as days to first flowering, days to $50 \%$ flowering (mid-bloom) and days to physiological maturity were collected as the number of days between planting date and date of appearance of first flower, date at $50 \%$ flowering and date at physiological maturity, respectively. At maturity, pods from all plants in each plot were harvested, sun-dried, and threshed, and weighed to obtain plot seed yield. Plot seed yield was used to determine yield per hectare by extrapolation.

Data analyses. Virus severity data were used to compute area under disease progress curve (AUDPC), as described by Campbell and Madden (1990), viz:

$\mathrm{AUDPC}=\sum_{i=1}^{n-1}\left(\frac{Y_{i}+Y_{i+1}}{2}\right)\left(t_{i+1}-t_{i}\right)$

Where:

$\mathrm{n}=$ number of successive readings, $\mathrm{Y} i=$ severity at time $i, t_{i}=$ number of days after the first observation on assessment date $i$.

Disease data (AUDPC, incidence, as well as agronomic data) were subjected to analysis of variance (ANOVA) across locations, using "agricolae" package (Felipe de Mendiburu,
2017). AUDPC and yield values were also analysed using the genotype, and genotype by environment (GGE) biplots, to understand the effects of genotype (G) and genotype by environment interactions (Yan et al., 2000; Yan, 2005).

The associations between viral infection and other traits was assessed using genotype by trait (GT) biplots (Yan and Rajcan, 2002). GGE and GT biplot analyses were carried out using "GGEBiplotGUI" package (Frutos et al., 2014). All analyses were implemented using $R$ Software Version 3.4.1 (R Core Team, 2017). GGE biplot analysis was based on model/ equation 7 (Yan, 2005) expressed as;

$$
P_{i j}=Y_{i j}-\mu-\beta_{j}=\alpha_{i}+\phi_{i j} \ldots \ldots \ldots \ldots \ldots \ldots
$$

Where:

$i$ is the value of genotype in environment $j, Y_{i j}$ is the genotype by environment two way table, $\mu$ is the grand mean, $\alpha_{i}$ is the genotype (row) main effect, $\beta_{j}$ is the environment (column) main effect, $\varphi_{i j}$ is the specific genotype by environment interaction, $P_{i j}$ is the matrix that is subjected to singular value decomposition (SVD).

For GT biplot analysis, model 2 (Yan and Rajcan, 2002) was used expressed as:

$$
\frac{T_{i j}-\bar{T}_{j}}{S_{j}}=\lambda_{1} \delta_{i 1} T_{j 1}+\lambda_{2} \delta_{i 2} T_{j 2}+\varepsilon_{i j}
$$

Where:

$T_{i j}$ is the average value of genotype $i$ for trait $j, \bar{T}_{j}$ is the average value of trait $j$ over all genotypes, $S_{j}$ is the standard deviation of trait $j$ among the genotype averages; $\lambda_{1}$ and $\lambda_{2}$ are the singular values for the first and second principal components, $\mathrm{PC} 1$ and $\mathrm{PC} 2$ respectively; $\delta_{i 1}$ and $\delta_{i 2}$ are the $\mathrm{PC} 1$ and $\mathrm{PC} 2$ scores, respectively, for genotype $i ; T_{j 1}$ and $T_{j 2}$ are the PC1 and PC2 scores, respectively, for 
trait $j$; and $\varepsilon_{i j}$ is the residual of the model associated with the genotype $i$ in trait $j$.

\section{RESULTS}

Area under disease progress curve. Genotypes, locations and seasons significantly $(\mathrm{P}<0.001)$ influenced the virus area under disease progress curve (Table 2). Interactions between genotypes and locations, genotype and season, location and season, as well as genotype by site by season also significantly influenced disease progress $(\mathrm{P}<0.001$ and $\mathrm{P}<0.01$, respectively) (Table 2). However, the greatest variation in disease progress was due to the effect of season $(63.6 \%)$; followed by genotypic effects at $12.5 \%$.

Genotype and genotype by environment biplot analysis of AUDPC data explained $93.06 \%$ of the variation in the data (Fig. 1). The first principal component (PC1/Axis1) accounted for $81.15 \%$; while the second principal component (PC2/Axis2) accounted for $11.19 \%$. The "which-won-where" feature of the GGEBiplotGUI package generated a biplot (Fig. 1) with seven sectors, with the most responsive (most susceptible) genotypes for each sector located at the respective vertex. The vertex genotypes were the most responsive, since they had the longest distance from the biplot origin.

From Figure 1, the three locations (Serere, Tororo and Budaka) formed a single megaenvironment with regard to AUDPC. In this mega-environment, the most responsive (most susceptible) genotypes were G50 (NE46), G13 (IT06K-91-11-1), G15 (IT07K-188-49), G14 (IT07K-187-24), G11 (IT06K-154-1), G6 (IT04K-227-4), G19 (IT07K-299-4, and G22 (IT97K-499-35); while the most resistant were G89 (WC48), G47 (NE43), G79 (WC33) and G71 (WC18).

It was also observed that genotypes G89, G32, G47, G71, G79, G82, G80, G84, and G63 had the lowest AUDPC values (Fig. 1). Ranking of cowpea genotypes on the basis of AUDPC, using a concentric circle biplot (Blanche et al., 2007) placed the most susceptible genotypes (with high AUDPC values) at or close to the center of concentric circles (Fig. 2), along the average tester axis (ATA). Accordingly, the most susceptible genotypes were G50, G13, G15, G7, G28, G10, G8, G18, G14, G20, G21, G11, G6, G3 and G9. On the other hand, genotypes further to the right on the ATA (opposite direction of the single arrow) and further below the stability axis had the lowest AUDPC values and thus

TABLE 2. Area under disease progress curve (AUDPC) across locations and seasons in a study of cowpea genotypes in eastern Uganda

\begin{tabular}{lrrc}
\hline Source of variation & Df & \multicolumn{2}{c}{ AUDPC } \\
\cline { 3 - 4 } & & Mean square & Variation $(\%)$ \\
\hline Blocks & 9 & $1214.99^{* * * *}$ & 0.88 \\
Replicates & 2 & $251.72^{\text {ss }}$ & 0.04 \\
Genotypes & 104 & $1488.17^{* * *}$ & 12.47 \\
Sites & 2 & $18452.16^{* * *}$ & 2.97 \\
Seasons & 1 & $788616.43^{* * *}$ & 63.56 \\
Genotype x site & 208 & $217.25^{* * *}$ & 3.64 \\
Genotype x season & 104 & $350.18^{* * *}$ & 2.94 \\
Site x season & 2 & $7525.95^{* * *}$ & 1.21 \\
Genotype x site x season & 208 & $134.161^{* *}$ & 2.25 \\
Residuals & 1228 & 101.36 & 10.03 \\
\hline
\end{tabular}

$* * *, * *, *$ significant at $\mathrm{P}<0.001,0.01$ and 0.05 , respectively; and $\mathrm{ns}=$ non-significant at 0.05 


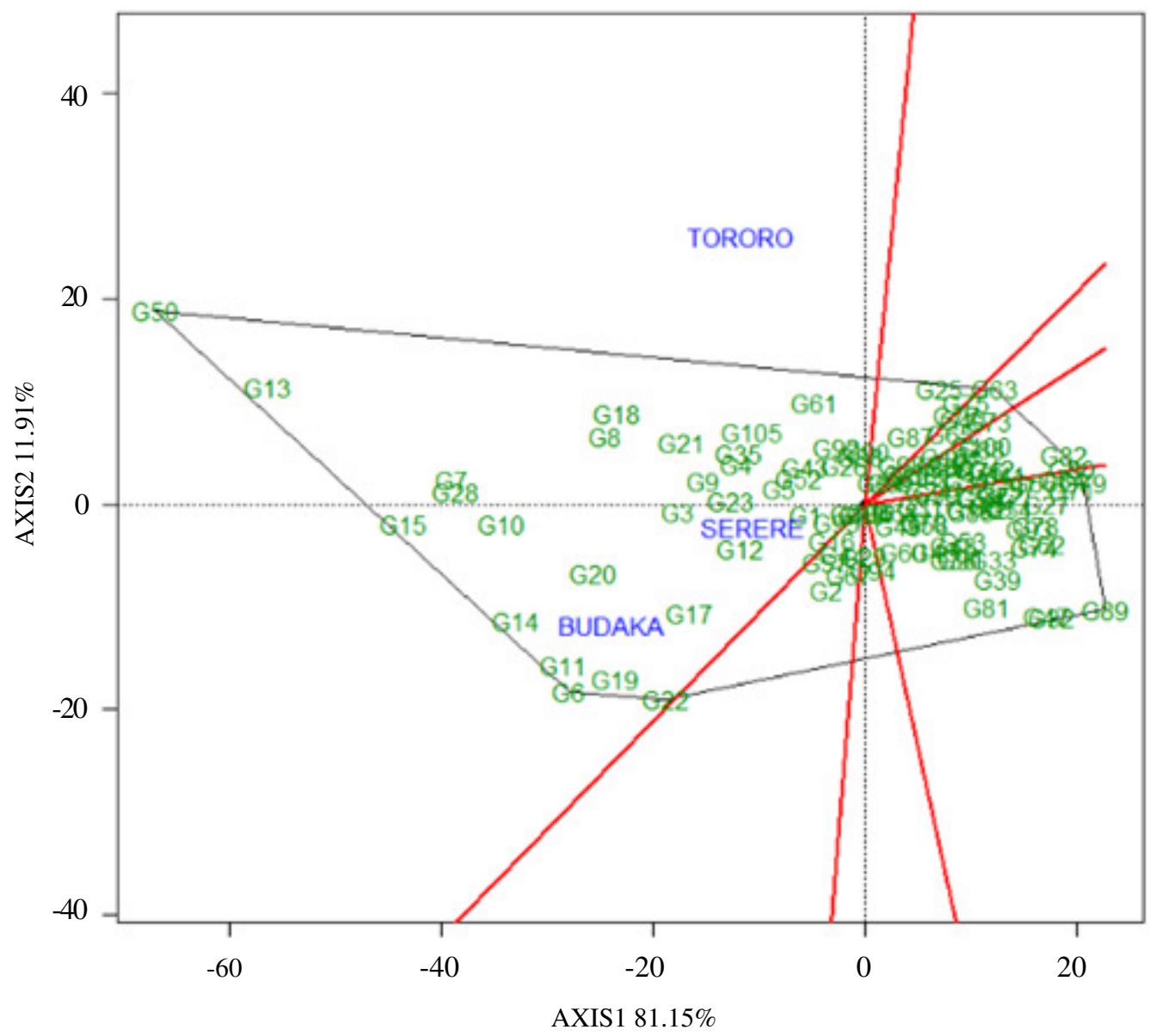

Figure 1. Mega-environment and most responsive genotypes based on AUDPC among cowpea genotypes across three locations in eastern Uganda using a genotype focused biplot.

the least susceptible. These genotypes included G89, G47, G32, G80, G84, G79, G82 and G71.

Virus incidence. The effects of blocks, genotypes, location and season significantly $(\mathrm{P}<0.001)$ influenced virus incidence (Table $3)$. The interactions between genotype and location $(\mathrm{P}<0.05)$, genotype by season $(\mathrm{P}<0.001)$ and location by season $(\mathrm{P}<0.001)$ also significantly influenced the level of virus incidence. However, genotype by site by season interactions had no significant influence on incidence. Season effects contributed to the greatest variation of virus incidence at
$28.5 \%$ followed genotypic effects at $24.5 \%$ (Table 3).

When incidence data were subjected to GGE biplot analysis ("which, won, where" feature), the resulting biplot explained up to 93.96\% of the variation in the data (Fig. 3); PC1 explained $86.58 \%$, while PC2 explained $7.38 \%$ of the variation in the data.

The three locations were grouped into two sectors/mega-environments. The first sector comprised of Serere and Tororo; while the second sector comprised of only Budaka. Genotypes G20 and G30 had the highest virus incidence in the first mega-environment; while genotypes G50, G13, G7, G10, G18, G11 had 


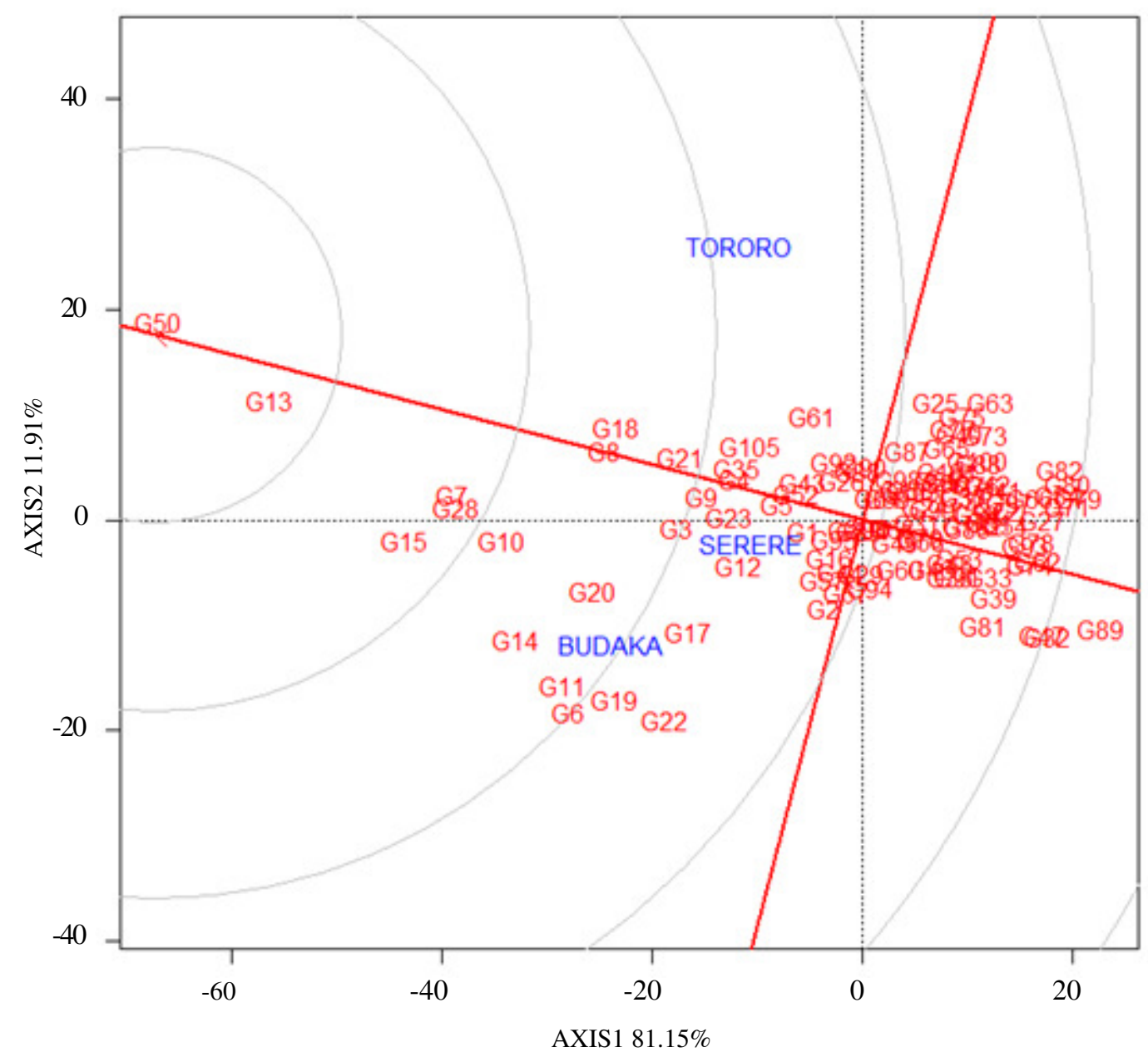

Figure 2. Ranking of genotypes in relation to the "most susceptible" to viral infection based on AUDPC values using a genotype focused biplot in a cowpea varietal study in Uganda.

the highest disease incidence in the second mega-environment (Fig. 3). On the other hand, genotypes G80, G71, G79, G82, G72, G84, G27 and G89 had the lowest virus incidence levels.

When genotypes were ranked using concentric circle biplot (Fig. 4), genotypes further to the left in the direction of the arrow on the ATA had high virus incidence level; while those to the right (opposite of the arrow) had low incidence levels (Fig. 4). Genotype G13 had the highest virus incidence (at the center of the smallest concentric circle); followed by G50, G20, G28 and G7. On the other hand,
G89, G82, G71, G79 and G74 further to the right on the ATA and below the stability axis had the lowest incidence.

Yield and other agronomic traits. Genotypes, location and site by season interactions significantly $\quad(\mathrm{P}<0.001)$ contributed to the variation in yield, days to first flower and days to $50 \%$ flowering as revealed by high percentage of explained variation (Table 4). Block and replicate effects also significantly influenced yield, but their contributions to explained variation were minimal. For the case of days to $75 \%$ maturity, 
TABLE 3. Variation for virus incidence across locations and seasons in a study of cowpea genotypes in eastern Uganda

\begin{tabular}{lrcc}
\hline Source of variation & Df & \multicolumn{2}{c}{ Incidence } \\
\cline { 3 - 4 } & & Mean square & Variation (\%) \\
\hline Blocks & 9 & $551.13^{* * *}$ & 0.46 \\
Replicates & 2 & $352.75^{\text {ns }}$ & 0.07 \\
Genotypes & 104 & $2557.32^{* * *}$ & 24.5 \\
Sites & 2 & $40743.99^{* * *}$ & 7.51 \\
Seasons & 1 & $309086.11^{* * *}$ & 28.48 \\
Genotype x site & 208 & $201.67^{*}$ & 3.86 \\
Genotype x season & 104 & $413.83^{* * *}$ & 3.97 \\
Site x season & 2 & $46850.17^{* * *}$ & 8.63 \\
Genotype x site x season & 208 & $183.24^{\text {ns }}$ & 3.51 \\
Residuals & 1228 & 168.01 & 19.01 \\
\hline
\end{tabular}

$* * *, * *, *=$ significant at $\mathrm{P}<0.001,0.01$ and 0.05 , respectively and $\mathrm{ns}=$ non-significant at 0.05

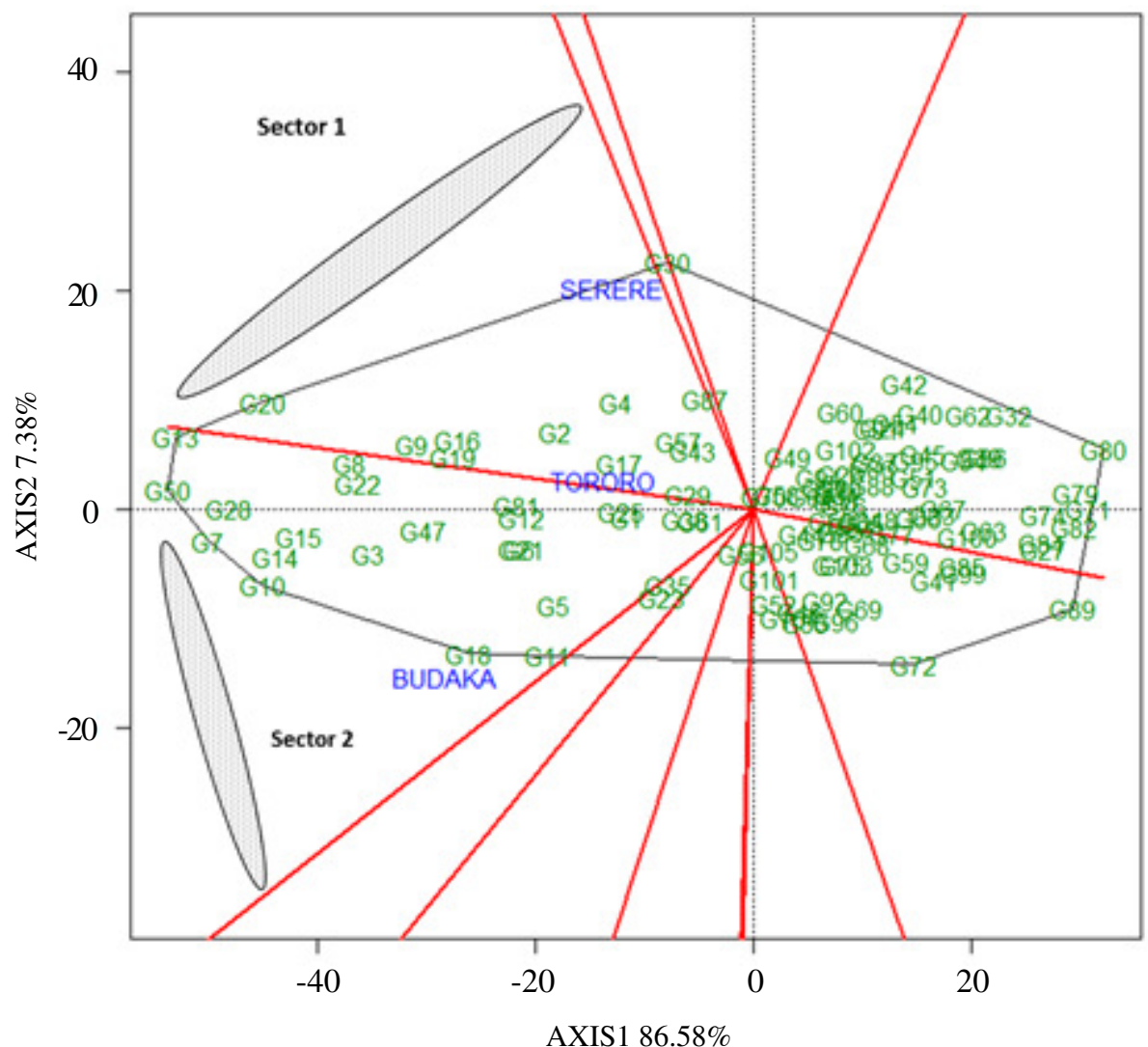

Figure 3. Mega-environments and most responsive genotypes for virus incidence in cowpea genotypes across locations in eastern Uganda using a genotype focused biplot. 


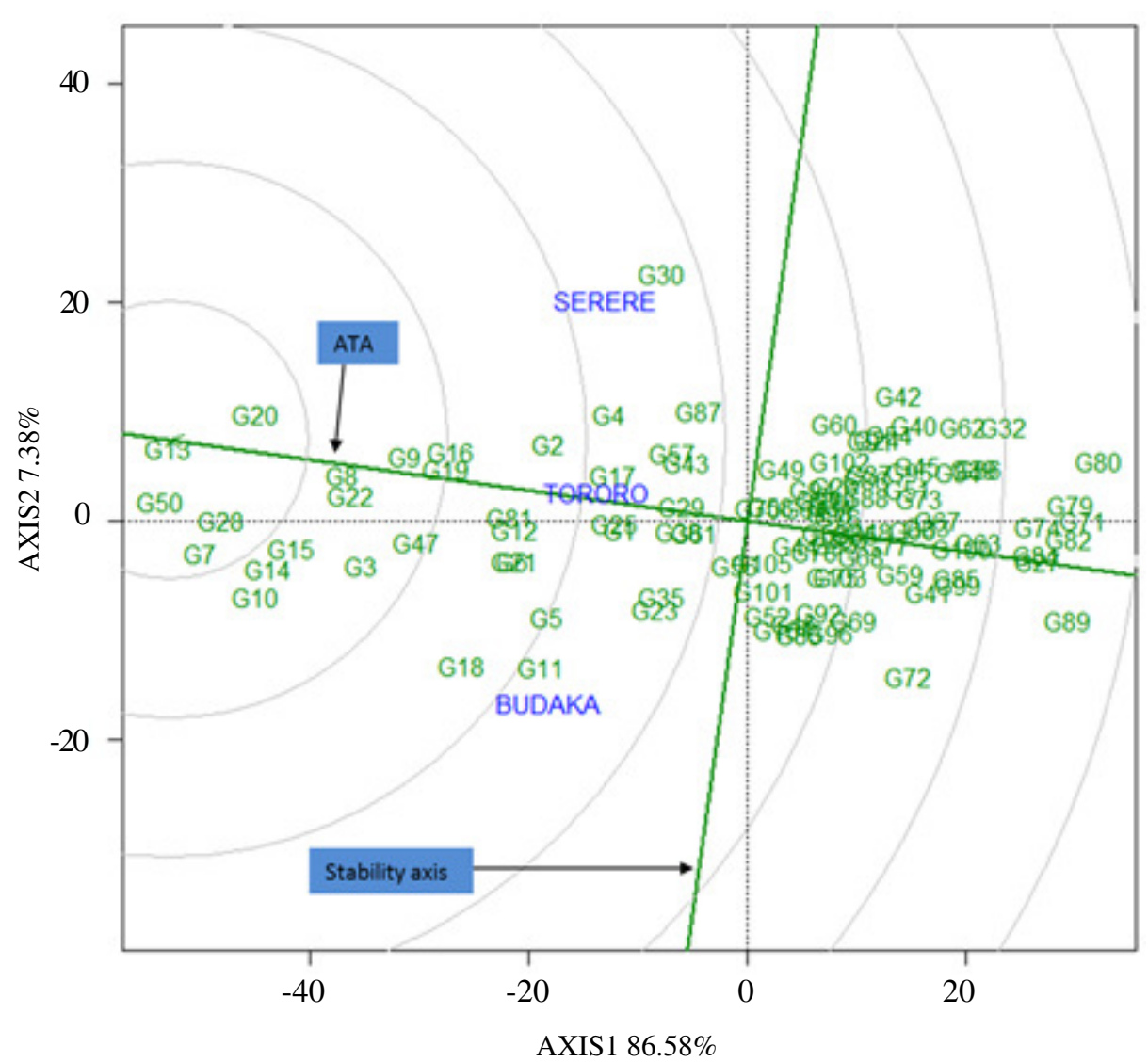

Figure 4. Ranking of cowpea genotypes based on virus incidence using a genotype focused concentric circle biplot in a cowpea varietal study in eastern Uganda.

season, genotype, genotype by site interactions, site and site by season and interactions had the greatest significant contribution to explained variation (of 9.15, 9.29, 9.33, 17.17 and 31.52\%) $(\mathrm{P}<0.001)$.

Analysis of yield data using GGE biplot revealed that the axis1 (PC1) explained 67.84\%; while axis2 (PC2) explained $17.73 \%$ of the total $\mathrm{G}$ and $\mathrm{GE}$ variation in grain yield (Fig. 5). Therefore, the first two axes explained $85.57 \%$ of the total variation. The three study locations formed a single mega-environment, with genotypes; G91 (WC51), G41 (NE37), G51 (NE48) and G54 (NE50) genotypes as winning genotypes. The average yield, for G91 (WC51), G41 (NE37), G51 (NE48) and G54 (NE50) were; 1384.7, 1156.5, 1191.4 and $976.2 \mathrm{~kg} \mathrm{ha}^{-1}$, respectively.
To identify desirable genotypes (both high yielding and stable across locations), a concentric circle biplot (Fig. 6) was used to rank genotypes in relation to the "ideal genotype". An "ideal" genotype (center of the innermost concentric ring/circle) is a point on the AEA ("absolutely stable") in the positive direction and has a vector length equal to the longest vectors of the genotypes on the positive side of ATA ("highest mean performance") (Yan and Tinker, 2006). Thus, G91, G51, G26, G78, G55, G41, G72, G87, G32, G93, G62 and G54 were closer to the "ideal genotype" and, therefore, more desirable than others. On the other hand, the poorest genotypes were G22, G29, G20, G95, G65, G19 and G90. 
Relationships between cowpea traits. Across all genotypes evaluated, virus incidence, severity and area under disease progress had a positive association as indicated by the acute angles between their vectors (Fig. 7). Days to first flowering, days to $50 \%$ flowering (mid-bloom) and days to $75 \%$ maturity also had acute angles between their vectors and, therefore, were positively correlated. However, there was a strong negative association between AUDPC and yield, average severity and yield, and incidence and yield as indicated by the large obtuse angles between their angles. It was observed that there was a near zero correlation between yield and days to first flowering, between yield and mid-bloom and between yield and maturity as indicated by the near perpendicular vectors (Fig. 7). Also, the three disease variables (AUDPC, severity and incidence) had a near zero correlation with all the maturity related variables (first flowering, mid-bloom and maturity) as indicated by perpendicular vectors.

Genotypes G50, G13, G7, G21 and G17 constituted a group of genotypes with similar trait profiles of high area under disease progress, high incidence and high severity values often with yield below the average mean. On the other hand, G89, G41, G84, G72, G93, and G78 were associated with low to medium virus infection levels, higher yields and similar maturity periods.

Not all genotypes that were resistant to virus infection were high yielding (Table 5). For example, G50 (NE46) which had the highest AUDPC, severity and incidence values yielded higher $\left(929 \mathrm{~kg} \mathrm{ha}^{-1}\right)$ than the overall mean $\left(670 \mathrm{~kg} \mathrm{ha}^{-1}\right)$ across the three locations. The yield of G50 was also higher than that of G89 (WC48) which was the most resistant genotype.

\section{DISCUSSION}

Area under disease progress and virus incidence. Seasonal differences had the greatest effect on AUDPC and incidence (Table 


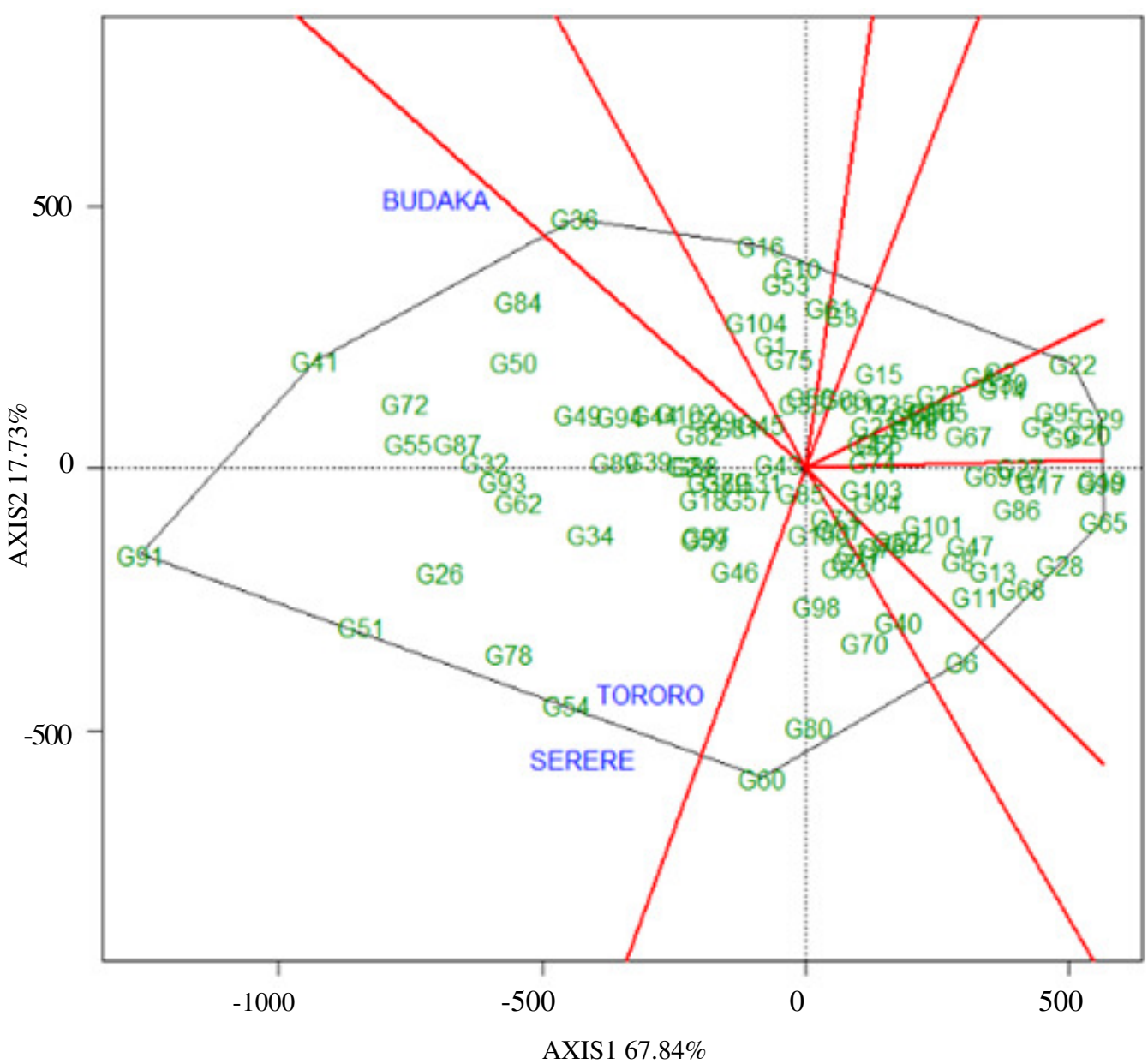

Figure 5. Biplot view of mega-environments and winning genotypes for grain yield using a genotype focused biplot in a cowpea study in eastern Uganda.

2 and Table 3) with lower virus incidence and AUDPC in the first season compared to the second season. However, this was contrary to the observations of Edema et al. (1997) and Adipala et al. (1999), who reported higher severities and incidences of viral diseases in the first season (wet season) than in the second dry season. Dry weather conditions are associated higher virus vector infestations due to high vector populations and greater mobility than the wet seasons (Edema et al., 1997; Taiwo et al., 2006; Kone et al., 2017a,b). Edema et al. (1997) and Adipala et al. (1999) attributed the higher viral incidence in the first (wet) season to short dry spells.

Genotypic effects were the second contributor to the total explained variation after season effects, indicating the presence of genetic variation among the genotypes. It is, therefore, possible to obtain sources of resistance among the existing pool of genotypes. Previous studies by Edema et al. (1997), Goenaga et al. (2008), Aliyu and Balogun (2011), also reported the influence of cowpea variety differences on viral disease severity and incidence. 


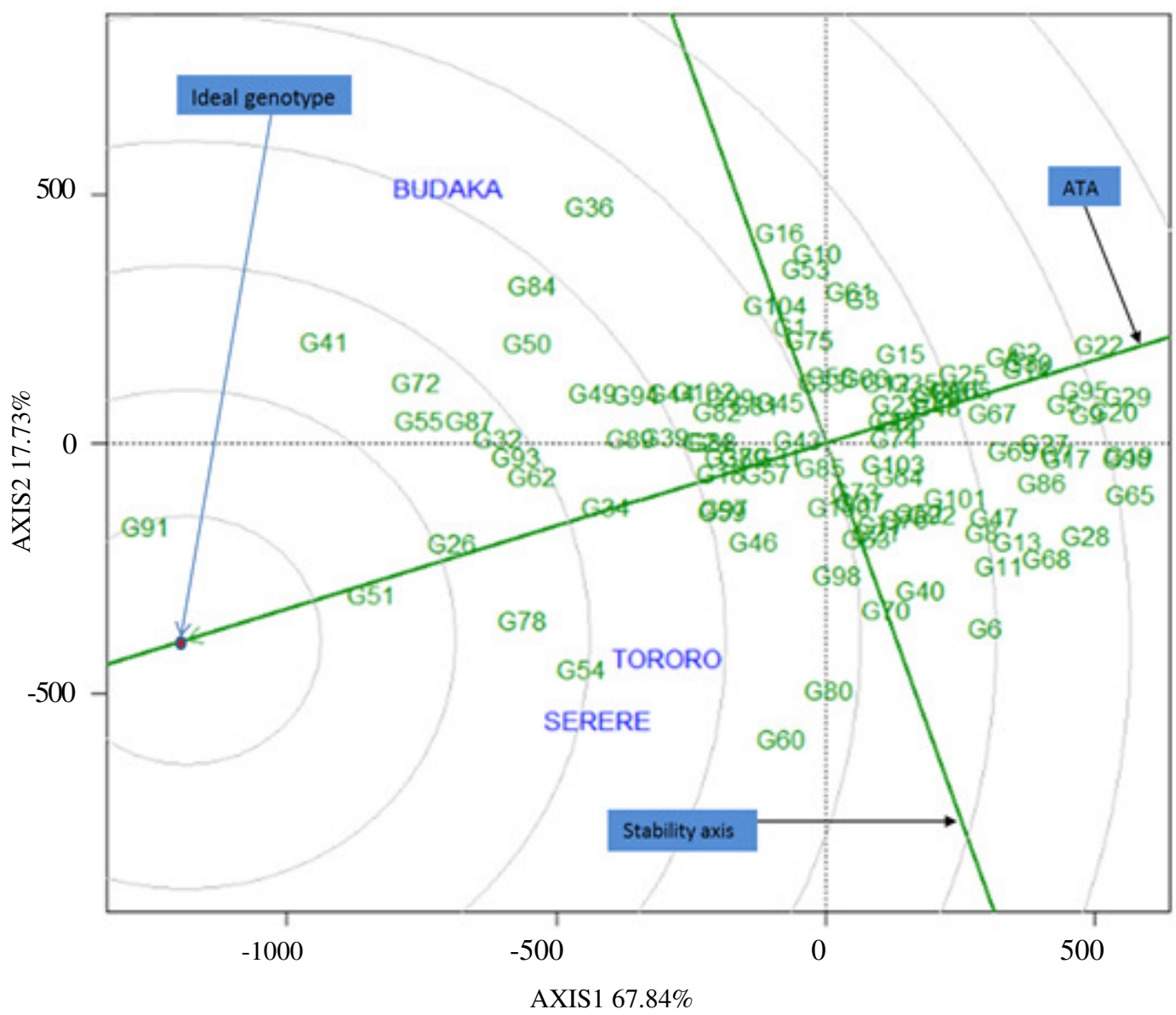

Figure 6. Ranking of cowpea genotypes relative to the ideal genotype for grain yield using a genotype focused concentric circle biplot in a varietal study in eastern Uganda.

In this study, it was possible to graphically identify susceptible or responsive genotypes (G50, G13, G15, G14, G11, G6 and G22), as well as resistant genotypes (G89, G32, G47, G79, G80, G82, G71, G84, and G62) (Figs. 1 - 4). Studies by Yan and Rajcan (2002), Yan and Tinker (2006) and Blanche et al. (2007) also reported on discriminative power of GGE biplots. Though none of the genotypes was completely immune to virus infection as previously reported by Mbeyagala et al. (2014), the identified resistant genotypes are potential sources of resistance for germplasm improvement, as well as cultivation if preferred by farmers.
Yield and other traits. Genotype, locations and location by season interactions had the greatest contribution to variation in yield and maturity indices (Table 3). This observed variability allows for selection of suitable genotypes for grain yield and maturity periods as previously reported (Hawkes, 1991).

Based on the median values for $75 \%$ maturity, most of the cowpea genotypes in this pool are medium maturing. The range of yield values indicated that both low to potentially high yielding genotypes exist in this collection. These findings collaborate those reported by Agbahoungba et al. (2017); thus it is possible to select genotypes with high yield potential from the assembled germplasm pool. 


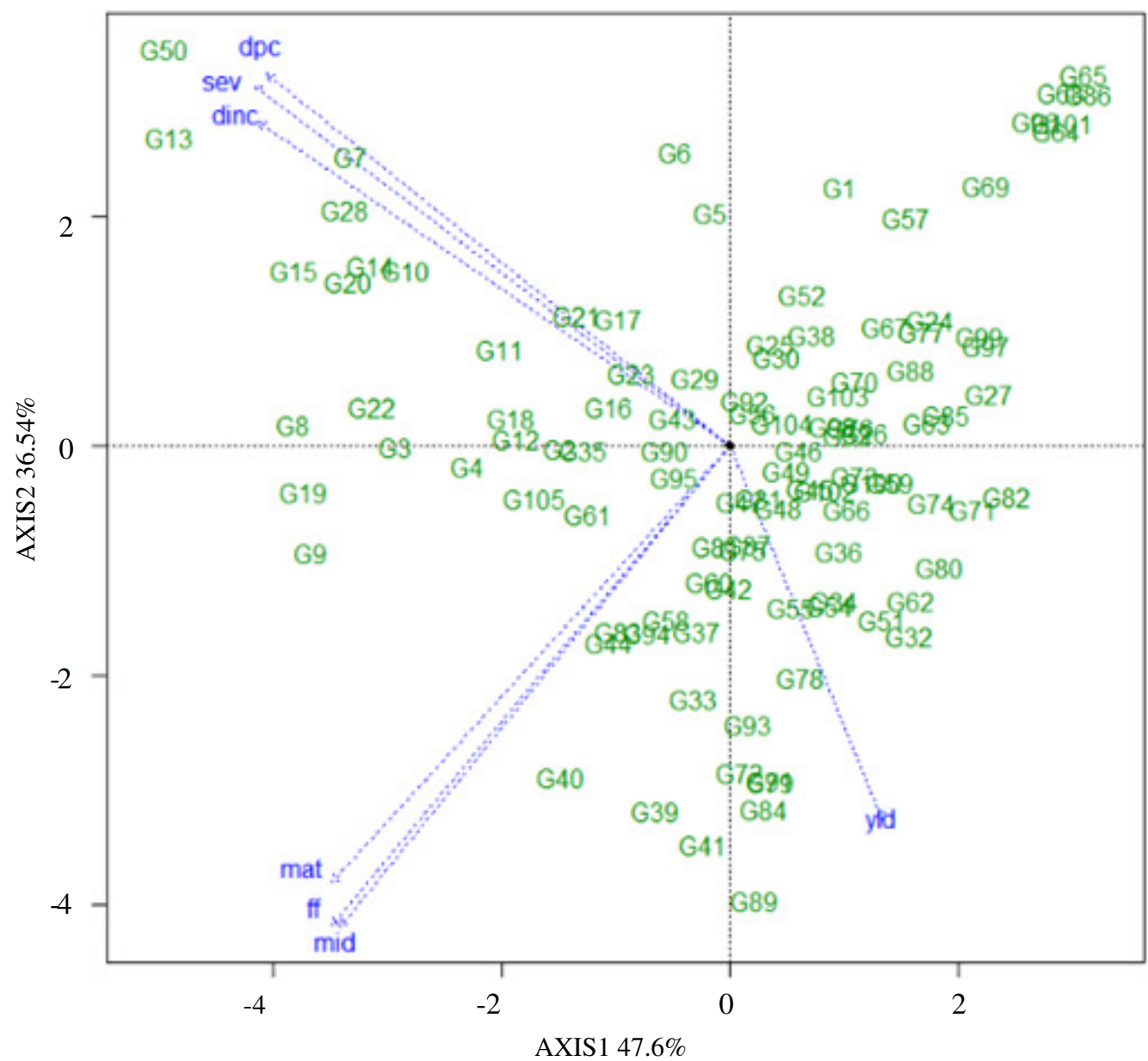

Figure 7. Genotype by trait biplot of 105 cowpea genotypes for seven traits across three locations (Budaka, Tororo and Serere) in eastern Uganda. yld $=$ yield $\left(\mathrm{kg} \mathrm{ha}^{-1}\right)$, mid $=$ mid-bloom, $\mathrm{ff}=$ days to appearnce of first flower, mat $=$ days to $75 \%$ maturity, dinc $=$ incidence, $\operatorname{sev}=$ average severity, dpc $=$ area under disease progress.

The three locations formed a single megaenvironment (Fig. 5), with G91, G41, G51, G26 and G54 as the high yielding and stable genotypes (Fig. 6). Ceccarelli (2012) suggested that good genotypes should have the best combination of high yield and high stability. Partitioning of test locations into mega-environments and deploying different genotypes for different mega-environments, is the best way to exploit positive genotype $\mathrm{x}$ environment interactions, while avoiding negative ones (Yan and Tinker, 2006). However, data from multiple seasons are required to verify the repeatability of the observed mega-environment pattern (Yan and Tinker, 2005, 2006).

Associations between traits. The genotype by trait biplot (GT) effectively revealed the interrelationships among cowpea traits (Fig. 7) and, thus helped to identify traits that were positively or negatively associated. For instance, there was a positive association between severity, incidence and AUDPC, as well as positive association between days to first flowering, mid-bloom and days to $75 \%$ maturity (Fig. 7). From the GT biplot, it was observed that some of the traits measured were 
TABLE 5. Means of AUDPC and other traits for 10 most resistant (top) and 10 most susceptible (bottom) cowpea genotypes at the three locations

\begin{tabular}{|c|c|c|c|c|c|c|c|c|}
\hline Code & Genotype & AUDPC & Yield & Severity & Incidence & $\begin{array}{l}\text { Number } \\
\text { of days } \\
\text { to first } \\
\text { flower }\end{array}$ & $\begin{array}{c}\text { Number } \\
\text { of days } \\
\text { to } 50 \% \\
\text { flowering }\end{array}$ & $\begin{array}{c}\text { Number } \\
\text { of days } \\
\text { to } 75 \% \\
\text { maturity }\end{array}$ \\
\hline G89 & WC48 & 39.77 & 865.20 & 1.50 & 23.64 & 52.18 & 55.42 & 86.42 \\
\hline G47 & NE43 & 42.56 & 538.66 & 1.58 & 58.41 & 48.94 & 52.22 & 83.33 \\
\hline G79 & WC33 & 42.71 & 744.68 & 1.62 & 24.30 & 51.92 & 55.67 & 83.36 \\
\hline G71 & WC18 & 42.86 & 558.70 & 1.55 & 23.76 & 48.12 & 51.41 & 80.64 \\
\hline G32 & NE15 & 43.26 & 1004.54 & 1.66 & 28.49 & 48.39 & 52.20 & 82.67 \\
\hline G62 & SECOW2W & 44.00 & 961.67 & 1.65 & 30.54 & 48.47 & 51.41 & 82.54 \\
\hline G80 & WC35A & 44.26 & 764.12 & 1.65 & 23.40 & 48.50 & 52.11 & 81.09 \\
\hline G27 & MU19 & 44.28 & 455.09 & 1.67 & 25.80 & 46.72 & 50.00 & 80.39 \\
\hline G74 & WC26 & 44.28 & 622.82 & 1.69 & 25.76 & 46.94 & 51.28 & 82.40 \\
\hline G84 & WC39 & 44.32 & 916.76 & 1.60 & 25.85 & 50.61 & 54.91 & 85.66 \\
\hline G50 & NE46 & 94.72 & 929.17 & 3.57 & 71.86 & 47.61 & 52.11 & 83.17 \\
\hline G13 & IT06K-91-11-1 & 86.88 & 502.55 & 3.11 & 71.92 & 49.19 & 53.11 & 84.33 \\
\hline G15 & IT07K-188-49 & 77.43 & 558.06 & 2.75 & 64.88 & 50.37 & 53.60 & 83.50 \\
\hline G7 & IT06K-121 & 75.31 & 444.01 & 2.74 & 69.60 & 48.72 & 51.76 & 83.10 \\
\hline G28 & MU20 & 73.38 & 426.62 & 2.67 & 68.60 & 48.86 & 53.61 & 82.75 \\
\hline G14 & IT07K-187-24 & 70.60 & 436.76 & 2.56 & 65.82 & 49.08 & 53.72 & 83.36 \\
\hline G10 & IT06K-147-1 & 69.87 & 608.06 & 2.58 & 66.30 & 49.11 & 53.11 & 82.74 \\
\hline G8 & IT06K-123-1 & 69.27 & 531.76 & 2.54 & 62.49 & 51.28 & 54.26 & 86.13 \\
\hline G20 & IT07K-300-12 & 66.51 & 376.85 & 2.61 & 67.66 & 48.52 & 53.36 & 85.37 \\
\hline G6 & IT04K-227-4 & 66.30 & 581.94 & 2.35 & 53.01 & 46.56 & 48.75 & 81.13 \\
\hline
\end{tabular}

redundant; for instance maturity traits (days to first flower, mid-bloom and days to maturity) and virus infection traits (severity, incidence and AUDPC). This indicates that any of these traits can be used to indirectly select for maturity and virus resistance. The use of GT biplots to describe interrelationships among traits has been reported previously for other crops such as soybean (Yan and Rajcan, 2002), barley (Yan and Tinker, 2005), wheat (Yan and Tinker, 2006) and forage sorghum (Aruna et al., 2016).

\section{CONCLUSION}

Our results showed that season and genotypic effects contributed greatly to the variation in response to virus infection in cowpea. Genotypes G89, G47, G32, G80, G84, G79, G82, and G71 showed low virus infection levels; thus could be used in cowpea improvement for resistance. These genotypes need to be subjected to enhanced virus levels, through artificial inoculation, to ascertain their reaction.

Based on yield data, the three locations formed a single mega-environment with G91 $\left(1,384 \mathrm{~kg} \mathrm{ha}^{-1}\right), \mathrm{G} 51\left(1,191.4 \mathrm{~kg} \mathrm{ha}^{-1}\right)$, and G26 (1,119.6 $\left.\mathrm{kg} \mathrm{ha}^{-1}\right)$ exhibiting stability and high yield. However, multi-season data are needed to confirm this pattern of megaenvironment delineation. The high yielding genotypes can be recommended for farmer cultivation after evaluation for acceptability. Positive correlations exist among the three maturity indices (days to first flowering, midbloom and days to $75 \%$ maturity) as well as among the three virus reaction indices (severity, incidence and AUDPC) suggesting that indirect genotype selection based on any of those traits in each category is possible. 


\section{ACKNOWLEDGEMENT}

This study was supported with funding from the McKnight Foundation, through the Collaborative Crop Research Program (CCRP). We are grateful to the partial funding provided by Carnegie Cooperation of New York (Grant \# RU/2016 /Carnegie/DFS/001) through the Regional Universities Forum for Capacity Building in Agriculture (RUFORUM).

\section{REFERENCES}

Adipala, E., Omongo, C.A., Sabiti, A., Obuo, J.E., Edema, R., Bua, B., Atyanga, A., Nsubuga, E.N. and Ogenga-Latigo, M.W. 1999. Pests and diseases on cowpea in Uganda: Experiences from a diagnostic survey. African Crop Science Journal 7(4):465-478.

Agbahoungba, S., Karungi, J., Odong, T.L., Badji, A., Sadik, K. and Rubaihayo, P. R. 2017. Stability and extent of resistance of cowpea lines to flower bud thrips in Uganda. African Crop Science Journal 25(1): 1-24. https://doi.org/10.4314/ acsj.v25i1.1

Aliyu, T.H. and Balogun, O.S. 2011. Effects of variety and planting density on the incidence of common viral diseases of cowpea (Vigna unguiculata) in a Southern Guinea savannah agro-ecology. Asian Journal of Plant Pathology 5:126-133. https://doi.org/10.3923/ajppaj. 2011.126.133

Aruna, C., Rakshit, S., Shrotria, P.K., Pahuja, S.K., Jain, S.K., Siva Kumar, S., Modi, N.D., Deshmukh, N.T., Kapoor, R. and Patil, J.V. 2016. Assessing genotype by environment interactions and trait associations in forage sorghum using GGE biplot analysis. The Journal of Agricultural Science 154(1):73-86. https://doi.org/ 10.1017/S0021859615000106

Bashir, M., Ahmad, Z. and Ghafoor, A. 2002. Cowpea aphid-borne mosaic potyvirus: A review. International Journal of Pest
Management 48(2):155-168. https:// doi.org/10.1080/09670870110118722.

Blade, S.F., Shetty, S.V.R., Terao, T. and Singh, B.B. 1997. Recent developments in cowpea cropping systems research. In: Singh, B.B., Mohan Raj, D.R., Dashiel, K.E. and Jackai, L.E.N (Eds.), Advances in cowpea research. Co-publication of International Institute of Tropical Agriculture (IITA) and Japan International Research Center for Agricultural Sciences (JIRCAS), IITA, Ibadan, Nigeria. pp. 114128.

Blanche, S.B., Myers, G. O. and Kang, M. S. 2007. GGE Biplots and Traditional Stability Measures for Interpreting Genotype by Environment Interactions. Journal of Crop Improvement 20(1):123-135. https:// doi.org/10.1300/J411v20n01_07

Campbell, C.L. and Madden, L.V. 1990. Introduction to Plant Disease Epidemiology. John Wiley \& Sons, New York, USA. 532pp.

Carsky, R.J., Vanlauwe, B. and Lyasse, O. 2002. Cowpea rotation as a resource management technology for cereal-based systems in the savannas of West Africa. In: Fatokun, C.A., Tarawali, S.A., Singh, B.B., Kormawa, P.M. and Tamò, M. (Eds.), Challenges and opportunities for enhancing sustainable cowpea pro-duction. Proceedings of the World Cowpea Conference III held at the International Institute of Tropical Agriculture (IITA), Ibadan, Nigeria, 4-8 September 2000. IITA, Ibadan, Nigeria. pp. 252-266.

Ceccarelli, S. 2012. Plant breeding with farmers -A technical manual. ICARDA, Aleppo, Syria. pp. xi +126 .

Edema, R., Adipala, E. and Florini, D. A. 1997. Influence of season and cropping system on occurrence of cowpea diseases in Uganda. Plant Disease 81:465-468.

Felipe de Mendiburu. 2017. agricolae: Statistical Procedures for Agricultural Research. R package version 1. 2-6. 
https://CRAN.R-project.org/package= agricolae

Frutos, E., Galindo, M.P. and Leiva, V. 2014. An interactive biplot implementation in $\mathrm{R}$ for modeling genotype-by-environment interaction. Stochastic Environmental Research and Risk Assessment 28:16291641.

Goenaga, R., Quiles, A. and Gillaspie, A.G. 2008. Assessing yield potential of cowpea genotypes grown under virus pressure. Hortscience 43(3):673-676.

Gumedzoe, M.Y.D., Thottappilly, G. and Asselin, A. 1997. Occurrence of southern bean mosaic virus (SVMV) in Togo and its interaction with some cowpea cultivars. African Crop Science Journal 5(2):215222.

Hawkes, J.G. 1991. The importance of genetic resources in plant breeding. Biological Journal of the Linnean Society 43(1):3-10.

Kone, N., Asare-Bediako, E., Silue, S., Kone, D., Koita, O., Menzel, W. and Winter, S. 2017a. Influence of planting date on incidence and severity of viral disease on cucurbits under field condition. Annals of Agricultural Sciences 62(1):99-104. https:/ /doi.org/10.1016/j.aoas.2017.05.005.

Kone, N., Asare-Bediako, E., Koita, O., Kone, D. and Winter, S. 2017b. Seasonal and spatial variation in the prevalence of viral diseases and associated aphid-borne viruses in cucurbits in Cote d'Ivoire. Annals of Agricultural Sciences 62(2):227-234. https://doi.org/10.1016/j.aoas.2017.12.005

Mbeyagala, E.K., Mukasa, B.S., Tukamuhabwa, P. and Bisikwa, J. 2014. Evaluation of cowpea genotypes for virus resistance under natural conditions in Uganda. Journal of Agricultural Science 6(10):176-187. https://doi.org/10.5539/ jas.v6n10p176

Ndiaye, M., Bashir, M., Keller, X.E. and Hampton, R.O. 1993. Cowpea viruses in Senegal, West Africa: Identities, distribution, seed transmission and sources of resistance. Plant Disease 77:999-1003.
Orawu, M., Melis, R., Milliano, W. D., Laing, M. and Adipala, E. 2005. Occurrence and prevalence of cowpea virus diseases in Uganda. African Crop Science Conference Proceedings 7:1279-1283.

Orawu, M., Obuo, J. and Omadi, R. 2015. Distribution and detection of cowpea viruses infecting cowpea in Uganda. American Journal of Plant Sciences 6(5):574-581. https://doi.org/10.4236/ ajps.2015.65062

R Core Team, 2017. R. A language and environment for statistical computing. R Foundation for Statistical Computing, Vienna, Austria. URL: https://www.Rproject.org/.

Taiwo, M.A., Hughes, J. d'A. and Oke, K.E. 2006. Studies on maize streak virus and Maize mottle/chlorotic stunt virus in Lagos, Nigeria. Plant Disease 90(2):199-202.

Taiwo, M.A. and Akinjogunla, O.J. 2006. Cowpea viruses: Quantitative and qualitative effects of single and mixed viral infections. African Journal of Biotechnology 5(19):1749-1756.

Timko, M. P., Ehlers, J. D. and Roberts, P. A. 2007. Cowpea (Chapter 3). In: Kole, C (Ed.), Genome mapping and Molecular Breeding in plants (Vol. 3). Berlin: Springer. pp. 50-67.

Timko, M.P. and Singh, B.B. 2008. Cowpea, a multifunctional legume (Chapter 10). In: In: Moore, P.H and Ming, R. (Eds.), Genomics of Tropical Plants. Berlin: Springer. pp. 227-258.

Yan, W. 2005. Use of biplot analysis in crop breeding. In: Swanson, C.S. (Ed.), Proceedings of the Eastern Wheat Workers and Southern Small Grain Workers Conference. May 9-12, 2005, Bowling Green, KY. University of Kentucky, USA. pp. 7-29.

Yan, W., Hunt, L. A., Sheng, Q. and Szlavnics, Z. 2000. Cultivar Evaluation and MegaEnvironment Investigation based on the GGE Biplot. Crop Science 40:597-605. 
Yan, W. and Rajcan, I. 2002. Biplot analysis of test sites and trait relations of soybean in Ontario. Crop Science 42:11-20.

Yan, W. and Tinker, N.A. 2005. An integrated Biplot analysis system for displaying, interpreting, and exploring genotype $\times$ environment interaction. Crop Science
45(3): 1004-1016. https://doi.org/10.2135/ cropsci2004.0076

Yan, W. and Tinker, N. A. 2006. Biplot analysis of multi-environment trial data: Principles and applications. Canadian Journal of Plant Science 86(3):623-645. 